\title{
Volatilization of ammonia in systems of treatment of swine manure with aquatic macrophytes
}

\author{
C. D. Pinaffi ${ }^{*}$ and C. H. Santos ${ }^{a}$ \\ a'Universidade do Oeste Paulista - UNOESTE, Rodovia Raposo Tavares, Km 572, Limoeiro, CEP 19026-310, \\ Presidente Prudente, SP, Brasil \\ *e-mail: camila_pinaffi@hotmal.com
}

Received: June 16, 2017 - Accepted: January 11, 2018 - Distributed: August 8, 2019

(With 7 figures)

\begin{abstract}
The usage of aquatic plants represents an alternative in the treatment of residues originating from swine. In these systems, one of the $\mathrm{N}$ removal methods is the ammonium $\left(\mathrm{NH}_{4}^{+}\right)$uptake and volatilization of ammonia $\left(\mathrm{NH}_{3}\right)$. In this way, the objective of this work was to evaluate the volatilization rates of $\mathrm{NH}_{3}$ in waste treatment systems swine fluids (SSF) with aquatic macrophytes, as well as the concentration of $\mathrm{NH}_{4}^{+}$present in the swine fluids. The experiment was carried out at Campus II/UNOESTE. The treatment systems were composed of 16 boxes of PVC and characterized as: $\mathrm{T} 1=$ Control sample $50 \%$ of SSF $/ 50 \%$ of water; $\mathrm{T} 2=50 \% \mathrm{SSF} / 50 \%$ water + Eichhornia crassipes (Mart.) Solms; $\mathrm{T} 3=50 \% \mathrm{SSF} / 50 \%$ water + Pistia stratiotes L.; T4 $=50 \% \mathrm{SSF} / 50 \%$ water + Salvinia auriculata Aubl. The design was randomized blocks, with 4 treatments and 4 replicates. The hydrogen potential $(\mathrm{pH})$ and the $\mathrm{NH}_{4}^{+}$content of the effluent were analyzed weekly, and the volatilization of $\mathrm{NH}_{3}$ by means of collectors installed in each treatment unit. The presence of aquatic macrophytes promoted the reduction of $\mathrm{NH}_{4}^{+}$concentration and of the $\mathrm{pH}$ values of swine fluids, and this resulted in the reduction of $\mathrm{NH}_{3}$ volatilization rates to the environment, with emphasis on the system with Eichhornia crassipes (Mart.) Solms, which presented the lowest rate of volatilization.
\end{abstract}

Keywords: greenhouse gases, phytoremediation, wastewater, environmental management.

\section{Volatilização de amônia em sistemas de tratamento de dejetos de suínos com macrófitas aquáticas}

\begin{abstract}
Resumo
A utilização de plantas aquáticas representa uma alternativa no tratamento de resíduos oriundos da suinocultura. Nestes sistemas, uma das formas de remoção de nitrogênio $(\mathrm{N})$ é a absorção de amônio $\left(\mathrm{NH}_{4}^{+}\right)$pelas plantas, entretanto, também ocorre a volatilização de amônia $\left(\mathrm{NH}_{3}\right)$. Dessa forma, o objetivo do trabalho foi avaliar as taxas de volatilização de $\mathrm{NH}_{3}$ em sistemas de tratamentos de dejetos líquidos de suínos (DLS) com macrófitas aquáticas, bem como a concentração de $\mathrm{NH}_{4}^{+}$presente nos dejetos. $\mathrm{O}$ experimento foi realizado em área de ambiente aberto no Campus II/UNOESTE. Os sistemas de tratamento foram constituídos de 16 caixas de PVC e caracterizados como: T1 $=$ Testemunha 50\% de DLS/50\% de água; T2 $=50 \%$ de DLS/50\% de água + Eichhornia crassipes (Mart.) Solms; T3 = 50\% de DLS $/ 50 \%$ de água + Pistia stratiotes L.; T4 $=50 \%$ de DLS/50\% de água + Salvinia auriculata Aubl. O delineamento adotado foi em blocos casualizados, com 4 tratamentos e 4 repetições. Foram analisados o potencial hidrogeniônico (pH) e o teor de $\mathrm{NH}_{4}^{+}$do efluente semanalmente, e a volatilização de $\mathrm{NH}_{3}$ por meio de coletores instalados em cada unidade de tratamento. A presença das macrófitas aquáticas proporcionou a redução da concentração de $\mathrm{NH}_{4}^{+} \mathrm{e}$ dos valores de pH dos dejetos líquidos de suínos, e isto resultou na redução das taxas de volatilização de $\mathrm{NH}_{3}$ ao meio ambiente, com destaque ao sistema com Eichhornia crassipes (Mart.) Solms, que apresentou a menor taxa de volatilização.
\end{abstract}

Palavras-chave: gases do efeito estufa, fitorremediação, efluentes, manejo ambiental.

\section{Introduction}

Pig farming represents a sector of great economic and social importance for Brazil (Gonzatto et al., 2013), responsible for increasing exports of meat and its industrialized products, and also for the generation of jobs. Brazilian pig farming occupies a prominent position in the world

scenario, where Brazil is the fourth largest producer and exporter of pork (ABCS, 2014).

However, pig farming is characterized as an activity with great potential for pollution, due to the effluent generation normally in the liquid form, with high load of organic and 
nutrient matter (mainly nitrogen and phosphorus, and also, potassium, calcium, sodium, magnesium, manganese, iron, zinc and copper) (Steinmetz et al., 2009). The pollutant load of liquid pig slurry may adversely affect environments as the water bodies, promoting the growth of microorganisms and the occurrence of eutrophication (Meade et al., 2011).

Excess nutrients, applied to the soil at rates higher than those for capture, may get in surface and groundwater due to the flow and leaching (Stone et al., 1998). To reduce the nutrient load into the environment, alternative or additional ways of treating wastewater should be implemented. An option for the additional treating is phytoremediation, that is, the use of plants and associated microorganisms as an instrument for containment, isolation, removal or reduction of contaminant concentrations in solid, liquid or gaseous media (EPA, 2000), at safe levels compatible with the protection of human health, as well as preventing the spread of harmful substances to the environment (Andrade et al., 2007).

The systems made with aquatic macrophytes are used to reduce the nutrient concentration of pig slurry, minimize the impacts on aquatic ecosystems (Poach et al., 2003), and provide an operationally passive form of wastewater treatment (Hunt and Poach, 2001; Kadlec and Knight, 1996). Furthermore, they can effectively treat great amounts of animal excrements (Knight et al., 2000), especially in the nitrogen (N) removal (Poach et al., 2003).

According to Vesilind and Morgan (2011), the $\mathrm{N}$ is an important element in biological reactions, and may be connected to components that produce a lot of energy, such as amino acids and amines, also known as organic $\mathrm{N}$. An intermediate element formed during the biological metabolism é the ammoniacal N. In accordance to Peng et al. (2005), the organic and ammoniacal $\mathrm{N}$ are the main forms presented in wastewater, and are considered indicators of recent pollution. The organic $\mathrm{N}$ is converted to ammoniacal under anaerobic and aerobic conditions, with the reduction of ammoniacal nitrogen concentrations contributing to the reduction of total nitrogen, and the temperature and $\mathrm{pH}$ have an impact on the bioactivity and volatilization processes.

The wetlands, systems artificially designed for utilizing aquatic macrophytes, remove $\mathrm{N}$ through sedimentation, absorption, organic matter accumulation, microbial assimilation, nitrification/denitrification and volatilization of ammonia (Brix, 1993; Johnston, 1991; Poach et al., 2003). Sooknah and Wilkie (2004) verify the reduction of $N$ because of the direct absorption by the aquatic macrophytes to the nitrification carried out by the nitrifying bacteria and the volatilization of non-ionized ammonia $\left(\mathrm{NH}_{3}\right)$ which occurs predominantly in high $\mathrm{pH}$ environments. Ammonia emissions characterize a major threat to the environment, due to their implications, such as changes in the rainfall $\mathrm{pH}$, contributions to the greenhouse effect, as well as effects on human and farmed animal health (Felix and Cardoso, 2004). Thus, monitoring these emissions is something fundamentally important for the control of atmospheric pollution.
Based on the previously said, this work aims at evaluating the losses of $\mathrm{N}$ to the atmosphere by volatilization of ammonia $\left(\mathrm{NH}_{3}\right)$ in pig slurry treatment systems, with and without the presence of aquatic plants, as well as the concentration of ammonium $\left(\mathrm{NH}_{4}^{+}\right)$present in pig slurry, with the hypothesis that aquatic plants are able to reduce the concentration of $\mathrm{NH}_{4}^{+}$present in swine manures, as well as to reduce losses of $\mathrm{N}$ by $\mathrm{NH}_{3}$ volatilization.

\section{Material and Methods}

The experiment, carried out in May and June of 2016, was conducted in an open environment at Campus II/UNOESTE, whose geographic coordinates are: Latitude $22^{\circ} 07^{\prime} \mathrm{S}$ e Longitude $51^{\circ} 09^{\prime} \mathrm{W}$, Presidente Prudente, São Paulo, Brazil. Located in a defined climate region, according to the climatic classification of Köppen, as Aw - tropical wet with dry winter, and average annual temperature of $29.2{ }^{\circ} \mathrm{C}$. The average annual rainfall is $1254.9 \mathrm{~mm}$ (CEPAGRI, 2017).

The treatment systems were composed of 16 polyvinyl chloride (PVC) containers with dimensions of $76.5 \mathrm{~cm}$ in height, $101.5 \mathrm{~cm}$ in superior diameter and $73.0 \mathrm{~cm}$ in inferior diameter, making a volume of $0.32 \mathrm{~m}^{3}$, in which only $0.25 \mathrm{~m}^{3}$ are used per container, margin adopted to avoid overflow.

Pig slurry was used, coming from the zootechnical center of Campus II/UNOESTE, for the composition of the treatments, which are: $\mathrm{T} 1=\mathrm{Control}$ sample $-50 \%$ pig slurry and 50\% water; T2 $=50 \%$ pig slurry and 50\% water +Eichhornia crassipes (Mart.) Solms (Figure 1); T3 = 50\%

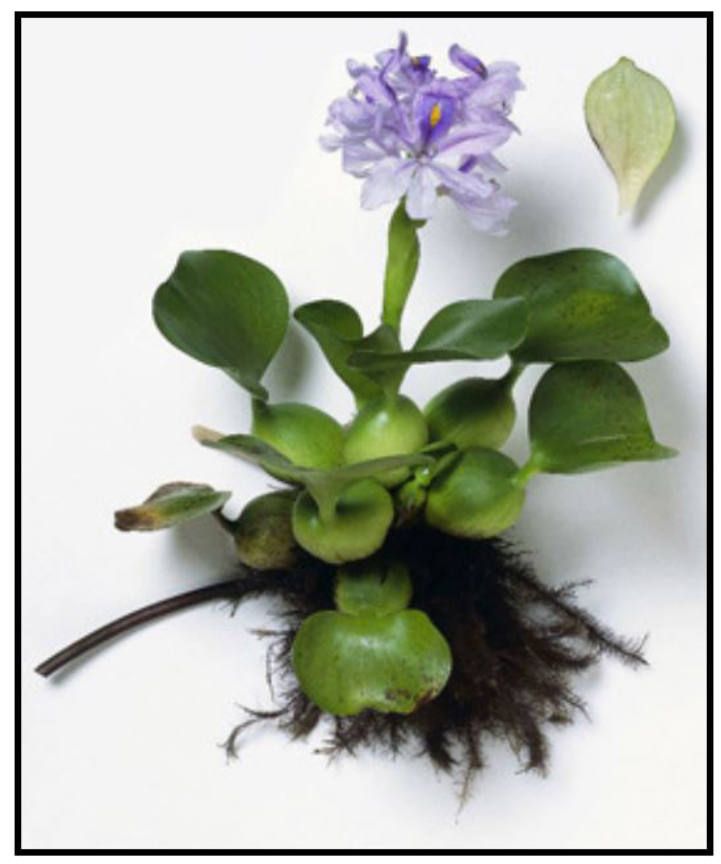

Figure 1. Eichhornia crassipes (Mart.) Solms (Lutzenberger, 1985). 
pig slurry and $50 \%$ water + Pistia stratiotes L. (Figure 2); $\mathrm{T} 4=50 \%$ pig slurry and $50 \%$ water + Salvinia auriculata Aubl. (Figure 3), distributed in a randomized block design (RBD), in split plots, with four repetitions. The plots are represented by the treatments (with and without the presence of aquatic macrophytes) and the split plots, by the collection periods.

The Eichhornia crassipes (Mart.) Solms is characterized by being a free floating aquatic plant, native of South America, belonging to the monocotyledonous class, Pontederidaceae family, Pontederiales order (Esteves, 1998), and by being an angiosperm with perennial life cycle (Bortolotto and

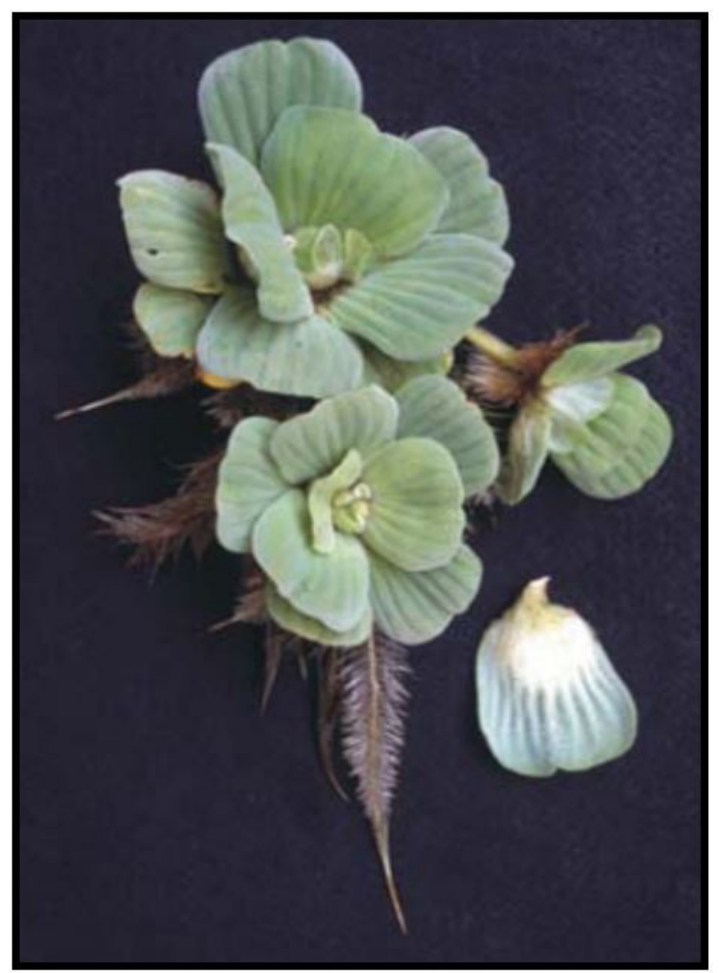

Figure 2. Pistia stratiotes L. (Pott and Pott, 2000).

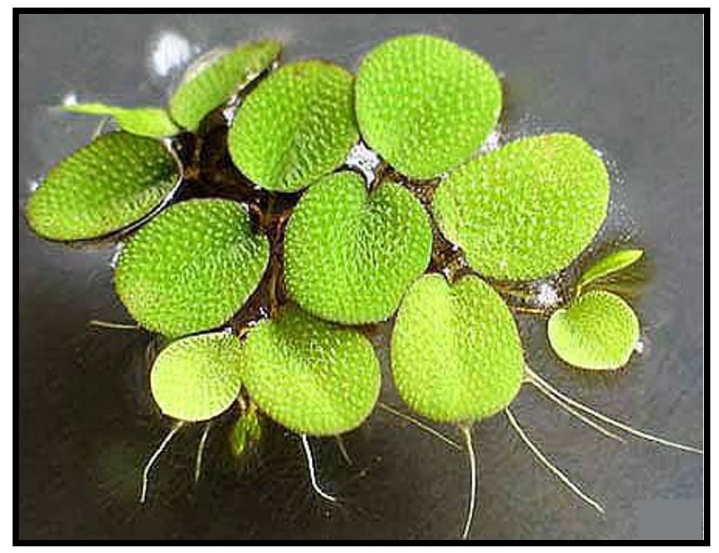

Figure 3. Salvinia auriculata Aubl. (Gomes, 2011).
Guarim Neto, 2005). Exotic in origin, it is distributed in all continents, in tropical semitropical latitudes and in some temperate countries (Metcalf and Tchobanoglous, 1991) and, in the absence of nutritional limitations, it rapidly develops in hot climate regions (Andrade et al., 2007).

The Pistia stratiotes L. is commonly known as water lettuce, belonging to the Araceae family (Kissmann and Groth, 1997), extensively distributed throughout the world. Its origin, which is attributed to Africa or South America (Lorenzi, 1982; Cardoso, et al., 2005), has not yet been fully defined. According to Pott and Pott (2000), $P$. stratiotes is considered a cosmopolitan tropical and subtropical species, being widely distributed throughout Brazil, occurring both in natural ecosystems and in aquatic environments impacted by anthropic activities (Henry-Silva and Camargo, 2000a).

Belonging to the family Salviniaceae, the Salvinia auriculata Aubl. is a free floating aquatic plant, of annual or perennial occurrence (Oliveira, 1981). It presents a wide native distribution in the neotropics, extending from Mexico and the Galapagos Islands through Central America and the Antilles and most of South America to the south of Brazil (Sculthorpe, 1967).

The aquatic macrophytes used were collected in lentic lakes from lands located in the West Paulista region, São Paulo, selected as young plants, with an established root system and aerial part of similar appearance. They were initially submitted to the environmental adaptation in boxes containing only water, at the experiment site, for a week. After this period, the treatment was initialized, and the amount of plants inserted in each experimental unit was determined to maintain an occupation of approximately $80 \%$ of the experimental units, as described by Henry-Silva and Camargo (2008).

During the experimental period, 16 samples of the effluent to analyse the $\mathrm{pH}$ and ammoniacal nitrogen in the ionized form $\left(\mathrm{NH}_{4}^{+}\right)$were weekly collected, at the periods of 0 (day in which the experiment was implanted), 7, 14, 21 and 30 days. The $\mathrm{pH}$ measurements were obtained using the Micronal bench digital $\mathrm{pH}$ meter. The determination of the $\mathrm{NH}_{4}^{+}$content was obtained by the Kjeldahl method, consisted of three stages: sample digestion, distillation with the Kjeldahl nitrogen distiller and titration with sulfuric acid, through the method presented by Malavolta et al. (1997). The method is based on the decomposition of organic matter by digestion of the sample with concentrated sulfuric acid at $350{ }^{\circ} \mathrm{C}$, in the presence of catalyst salts that accelerate the oxidation of organic matter. The digestion will be terminated after obtaining a colorless or slightly greenish liquid. The nitrogen present in the resulting acid solution is determined by steam distillation, collected by the boric acid $2 \%(\mathrm{~m} / \mathrm{v})$ solution and indicators, followed by titration with sulfuric acid $(0.02 \mathrm{~N})$.

For the quantification of $\mathrm{NH}_{3}$ volatilization a PVC collector base (Figure 4), with $15.0 \mathrm{~cm}$ in diameter and $14.0 \mathrm{~cm}$ in height, was placed in each treatment box, fixed to a $4.0 \mathrm{~cm}$ thick Styrofoam board, with a center opening beneath the surface of the effluent. Each base was protected 


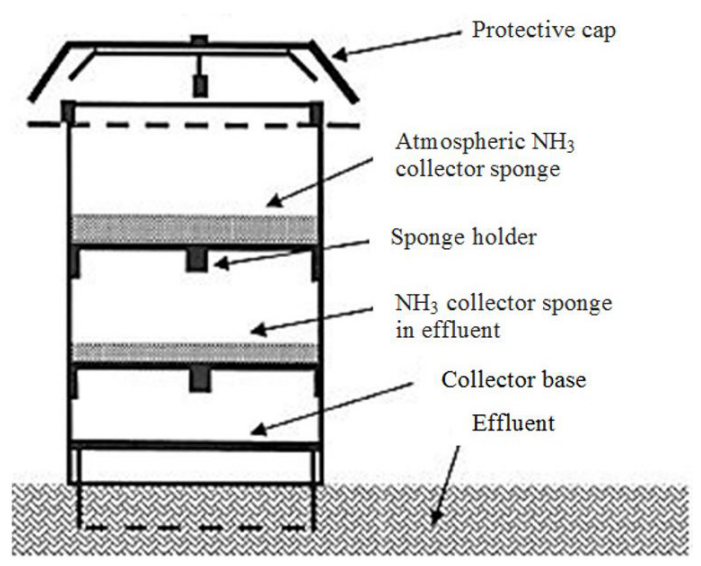

Figure 4. $\mathrm{NH}_{3}$ collector scheme (adapted from Ros et al., 2005).

at the top with a polyethylene plate with $20.0 \mathrm{~m}$ in diameter, and a $2.0 \mathrm{~cm}$ opening between the plate and the collector base was kept, for establishing a steam pressure deficit and, thus, the $\mathrm{NH}_{3}$ volatilization could happen. Inside the PVC base a screen with an effluent height of $4.0 \mathrm{~cm}$ was place, fixed to a glass petri dish which housed in its interior a sponge with $2.0 \mathrm{~cm}$ thick and $7.0 \mathrm{~cm}$ width.

The sponges, moistened with $30.0 \mathrm{~mL}$ of phosphoric acid $\left(0.167 \mathrm{~mol} \mathrm{~L}^{-1}\right)$ to capture the volatilized $\mathrm{NH}_{3}$ of the effluent, were replaced at the periods of 1, 4, 8, 12, 19 and 27 days after placing the collectors. In the collections, the sponges were gathered, stored in a plastic box with a lid and immediately taken to the laboratory of clinical analysis of vegetal tissues/UNOESTE to extract the ammonium phosphate solution $\left(\left(\mathrm{NH}_{4}\right)_{3} \mathrm{PO}_{4}\right)$ formed from the chemical reaction between $\mathrm{NH}_{3}$ and phosphoric acid $\left(\mathrm{H}_{3} \mathrm{PO}_{4}\right)$. Their washings were performed with $500.0 \mathrm{~mL}$ deionized water, in five continuous washings of $100.0 \mathrm{~mL}$ each. Finally, an aliquot of $20.0 \mathrm{~mL}$ of the solution was submitted to distillation with the Kjheldad distiller by the method described by Cantarella and Trivelin (2001).

The efficiencies of the treatments in the reduction of the content of $\mathrm{NH}_{4}^{+}$were calculated according to Equation 1:

$$
E(\%)=[(C i-C f) / C i] \times 100
$$

In which: $\mathrm{E}=$ Removal efficiency (\%); $\mathrm{Ci}=$ Initial concentration $\left(\mathrm{mg} \mathrm{L}^{-1}\right) ; \mathrm{Cf}=$ Final concentration $\left(\mathrm{mg} \mathrm{L}^{-1}\right)$.

The results were put under analysis of variance by the Test $\mathrm{F}$ and the comparison of the means by the Tukey Test, at the level of 5\% probability, with software Assistat 7.7.

\section{Results and Discussion}

The values of Test $F$, obtained by the contrast of means between the treatments (Table 1), show that there was a significant difference between the plant species used and the collection periods for the following variables: $\mathrm{pH}$ ammonium $\left(\mathrm{NH}_{4}^{+}\right)$and ammonia $\left(\mathrm{NH}_{3}\right)$.
Table 1. Values of $\mathrm{F}$ for $\mathrm{pH}, \mathrm{NH}_{4}^{+}$and the volatilization of $\mathrm{NH}_{3}$ calculated based on the Tukey Test, at the level of $5 \%$ probability, in the treatments with aquatic species, in collection periods.

\begin{tabular}{|c|c|c|c|}
\hline \multirow{2}{*}{ Variation factors } & \multirow{2}{*}{ pH } & $\mathrm{NH}_{4}^{+}$ & $\mathrm{NH}_{3}$ \\
\hline & & \multicolumn{2}{|c|}{$\left(\mathrm{mg} \mathrm{L}^{-1}\right)$} \\
\hline Treatment (a) & $27.58^{*}$ & $12.69 *$ & $15.05 *$ \\
\hline Collection periods (b) & $239.36^{*}$ & $299.37 *$ & $28.67^{*}$ \\
\hline Interaction $(a) \times(b)$ & $3.62 *$ & $0.90 \mathrm{~ns}$ & $4.00^{*}$ \\
\hline $\mathrm{CV}(\mathrm{a})(\%)$ & 1.49 & 10.47 & 31.25 \\
\hline DMS (a) & 0.22 & 0.96 & 91.04 \\
\hline $\mathrm{CV}(\mathrm{b})(\%)$ & 1.47 & 20.81 & 30.33 \\
\hline DMS (b) & 0.21 & 0.94 & 81.62 \\
\hline
\end{tabular}

*significant at the level of $1 \%$ probability $(\mathrm{p}<0.01)$; ns $=$ not significant.

The $\mathrm{pH}$ values (Figure 5) decreased, throughout the collection periods, in all treatments. It was possible to notice that in the period of 7 days, the Eichhornia crassipes (Mart.) Solms provided a significant reduction in the $\mathrm{pH}$ compared to the others, and according to Granato (1995), Eichhornia crassipes (Mart.) Solms, in contact with alkaline solutions, has the ability of decreasing the $\mathrm{pH}$ of these solutions, due to the absorption of the potassium, calcium and magnesium nutrients, respectively, which are all present in the medium. According to Esteves (1998), the organic matter decomposition process reduces the $\mathrm{pH}$, since there is an increase in the carbon dioxide $\left(\mathrm{CO}_{2}\right)$ concentration in the medium and, at the same time, the consumption of dissolved oxygen. Lin et al. (2005) also observed a reduction in the $\mathrm{pH}$ of the effluent from de Litopenaeus vannamei nurseries treated with constructed wetland. According to Shah et al. (2015), a pH of 6.0-9.0 is the most adequate for the aquatic macrophytes performance and, in accordance with CONAMA (2011) Resolution no. $430 / 2011$, the $\mathrm{pH}$ values of the effluent from any polluting source, to be directly released in the receiving body, must be between 5.0 and 9.0. Thus, the results found in the treatments with plant species are in agreement with the ones required by the Brazilian legislation.

For Henry-Silva and Camargo (2000b), the highest $\mathrm{pH}$ found only in the effluent is probably related to the photosynthesis of the phytoplankton present in the site, which, by assimilating the $\mathrm{CO}_{2}$ available in the water, increases the $\mathrm{pH}$ values of the medium.

Silva et al. (2014) found out that the effluent from water supply channels with tambaqui farming treated with Eichhornia crassipes (Mart.) Solms showed lower $\mathrm{pH}$ values when compared to the treatments without plants. According to the authors, it happens because of the removal of bases that enable the growth of Eichhornia crassipes (Mart.) Solms. Gentelini et al. (2008) observed that the organic pisciculture effluent, before passing through the system with aquatic macrophytes, was slightly alkaline, with a $\mathrm{pH}$ of 7.03 , becoming somewhat 
acid after crossing the system. This same pattern of $\mathrm{pH}$ reduction, after passing through the treatment system, was observed by Henry-Silva and Camargo (2006) with three floating macrophytes, Eichhornia crassipes (Mart.) Solms, Pistia stratiotes L. and Salvinia molesta D. S. Mitch., in the treatment of pisciculture effluent.

In relation to the $\mathrm{NH}_{4}^{+}$concentration in the effluent, it should be noted that there was no significant interaction between the treatments (without and with the plants) and between the collection periods. However, after evaluating the means obtained in each treatment (Figure 6), it was possible to notice that the Eichhornia crassipes (Mart.) Solms species statically differed from the others by presenting a lower $\mathrm{NH}_{4}^{+}$content in its effluent and, therefore, higher efficiency in the removal of this element $(93.4 \%$, according Table 2) in a 30 day detention time. Reidel et al. (2005), when analysing the refrigerated effluent treatment system with Eichhornia crassipes (Mart.) Solms, found that the industrial effluent presented average concentration of $79.85 \mathrm{mg} \mathrm{L}^{-1}$ of $\mathrm{NH}_{4}^{+}$, and the reductions of this element

Table 2. Initial and final values of the content of $\mathrm{NH}_{4}^{+}$in the treatments with aquatic species.

\begin{tabular}{lccc}
\hline \multirow{2}{*}{\multicolumn{1}{c}{ Treatments }} & \multicolumn{3}{c}{$\mathbf{N H}_{\mathbf{4}}^{+}\left(\mathbf{m g ~ ~ L ^ { - 1 } )}\right.$} \\
\cline { 2 - 4 } & Initial & Final & E (\%) \\
\hline Control sample & 9.87 & 2.38 & 75.9 \\
Eichhornia crassipes (Mart.) & 8.89 & 0.58 & 93.4 \\
Solms & & & \\
Pistia stratiotes L. & 9.52 & 3.15 & 66.9 \\
Salvinia auriculata Aubl. & 10.29 & 2.45 & 76.2 \\
\hline
\end{tabular}

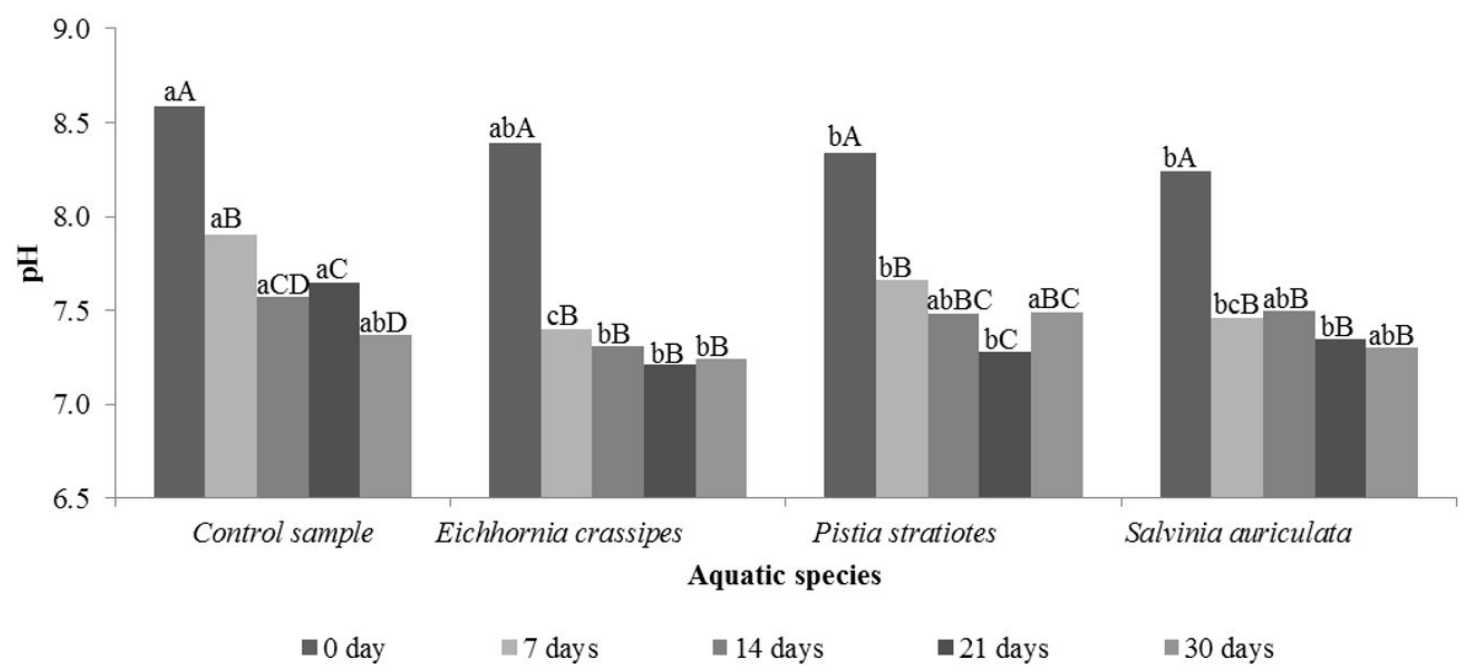

Figure 5. $\mathrm{pH}$ values obtained in the treatments with aquatic species, in five collection periods. Reference value according to CONAMA Resolution $\mathrm{n}^{\circ} 430 / 2011=\mathrm{pH}$ : 5-9. DMS for collection periods $=0.21 ; \mathrm{CV}(\%)=1.47$ classification on lowercase letters. DMS for aquatic species $=0.22 ; \mathrm{CV}(\%)=1.49$ classification on capital letters. Tukey Test was applied at the level of $5 \%$ probability.

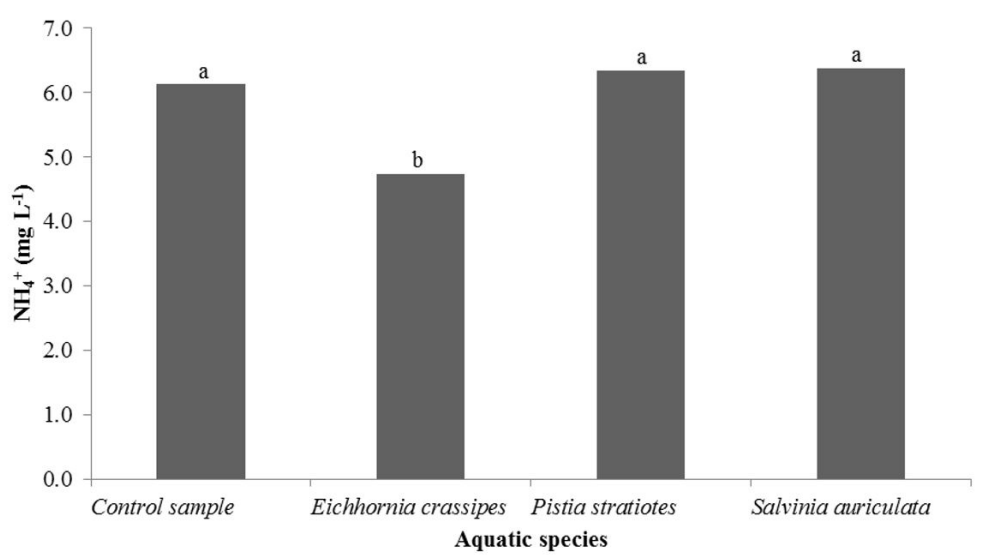

Figure 6. Available $\mathrm{NH}_{4}^{+}$concentration, in $\mathrm{mg} \mathrm{L}^{-1}$, in the treatments with aquatic species. Reference value according to CONAMA Resolution $\mathrm{n}^{\circ} 430 / 2011=\mathrm{NH}_{4}^{+}: 20.0 \mathrm{mg} \mathrm{L}^{-1}$. DMS $=0.96$; CV $(\%)=10.47$. The means followed by the same letter are not statistically different among themselves. Tukey Test was applied at the level of $5 \%$ probability. 
were $58.9 \%$ for a five day detention time, $86.1 \%$ for seven days and $97.7 \%$ for ten days, thus increasing the removal efficiency with an increased hydraulic detention time.

Sezerino and Philippi (2000) highlight that, in such treatment systems with plants, approximately $74.0 \%$ from the $\mathrm{NH}_{4}^{+}$removal may be associated with the plant uptake. CONAMA Resolution no. 430/2011 puts a limit in the concentration of the $\mathrm{NH}_{4}^{+}$ion to values of $20 \mathrm{mg} \mathrm{L}^{-1}$ in effluents from any polluting source. Therefore, the values obtained in the treatments submitted to the aquatic plants (Figure 6) are in accordance with the Brazilian legislation.

The $\mathrm{NH}_{3}$ volatilization (desorption to the atmosphere) is a physical process of disengaging this gas from the dissociation of the $\mathrm{NH}_{4}{ }_{4}$ ion in aquatic environments with high $\mathrm{pH}$ values (Assunção, 2009). The $\mathrm{NH}_{3}$ volatilization was observed in the interaction between treatments with aquatic macrophytes and the evaluation periods (Figure 7).

According to Figure 7, this volatilization was higher in the control sample treatment, stressing that the differentiation occurred, mainly, after the period of 12 days of collection. It is also stated that the systems containing aquatic species provided lower losses of $\mathrm{NH}_{3}$, with a noticeable decrease during the evaluation period. According to Körner and Vermaat (1998) and Sooknah and Wilkie (2004) in treatment systems with aquatic macrophytes, the removal of $\mathrm{N}$ happens by the direct absorption of the plant, by the action of microorganisms fixed in the roots and by the $\mathrm{NH}_{3}$ volatilization itself.

It is noteworthy that at the initial collection period ( 1 to 4 days), the $\mathrm{NH}_{3}$ concentration was higher in the four treatments proposed. According to Assunção (2009), when the $\mathrm{pH}$ is high, he balance between the free $\mathrm{NH}_{3}$ and $\mathrm{NH}_{4}^{+}$ion tends to shift toward the $\mathrm{NH}_{3}$ formation. For values above 9.26 there's a predominance of $\mathrm{NH}_{3}$ (practically $100 \%$ at $\mathrm{pH}$ near 11.0) and for values close to neutrality (between 6.0 and 7.0), practically all $\mathrm{NH}_{3}$ is in the ionized form.
For Kiehl (1985), the $\mathrm{NH}_{3}$ losses increase when the compound reaction is in the alkalinity zone and when the $\mathrm{pH}$ reaches values above 8.0 and 9.0, a large part of $\mathrm{N}$ turned into $\mathrm{NH}_{3}$, and may be lost in the atmosphere. The balance represented by the reaction $\mathrm{NH}_{4}^{+} \leftrightarrow \mathrm{NH}_{3}+\mathrm{H}^{+}$, at $\mathrm{pH}$ values around neutrality, is shifted to the left, and there is a predominance of $\mathrm{NH}_{3}$ only to $\mathrm{pH}$ values above 8.5 (SCHMIDELL et al., 2007). Probably, due to the fact that the $\mathrm{pH}$ of the effluent was higher (above 8.0) in the first days ( 0 to 7 days) (Figure 5), the release of $\mathrm{NH}_{3}$ was higher. Mkhabela et al. (2009) stated that the initial high $\mathrm{pH}$ of the slurry is a factor that contributes to such emissions, and Meade et al. (2011) observed that 95\% of the $\mathrm{NH}_{3}$ emissions happened in the first 24 hours after applying the slurry.

Gonzatto et al. (2013), when evaluating, under field conditions, the $\mathrm{NH}_{3}$ volatilization and $\mathrm{N}_{2} \mathrm{O}$ emission after applying the pig slurry in maize, observed that approximately $80.0 \%$ of the $\mathrm{N}$ losses by volatilization happened in the first 22 hours after applying the slurry, quickly reducing with time. According to the authors, this kinetic observed in the $\mathrm{NH}_{3}$ emissions may be attributed to the high content of $\mathrm{NH}_{4}^{+}$of the pig slurry, which is one of the factors that influence the $\mathrm{NH}_{3}$ volatilization (Sommer and Hutchings, 2001).

Harper et al. (2004) state that the main factors that can be correlated to the $\mathrm{NH}_{3}$ volatilization in pig ponds are the wind speed, temperature, $\mathrm{NH}_{4}^{+}$concentration and the effluent $\mathrm{pH}$. Thus, it is observed that the $\mathrm{NH}_{4}^{+}$concentrations found in the pig slurry (Figure 6) were higher in the beginning of the experiment; besides, in the aquatic macrophytes treatment, the $\mathrm{NH}_{3}$ volatilization may have been reduced from the 12 days of collection, compared to the control sample treatment (Figure 7), due to the high absorption of $\mathrm{NH}_{4}^{+}$by the plants, as can be observed in Figure 6 . In the treatment with Eichhornia crassipes (Mart.) Solms,

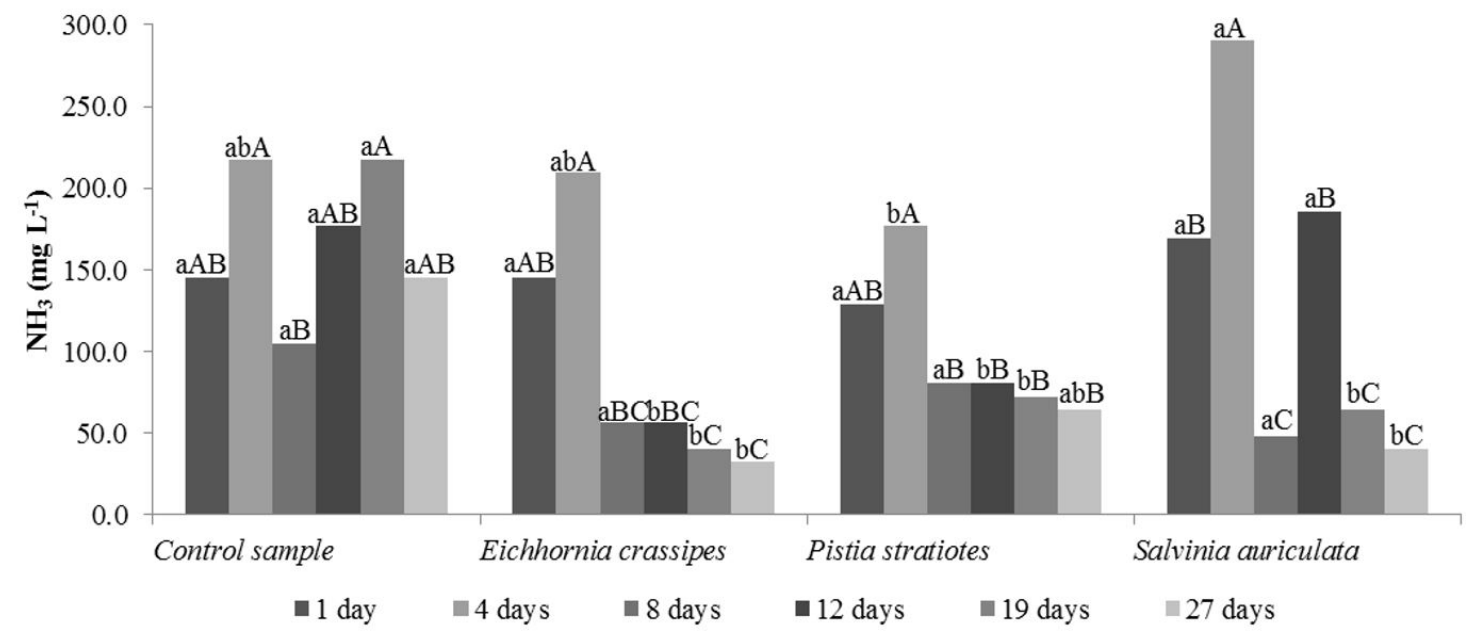

Figure 7. Available $\mathrm{NH}_{3}$ concentration, in $\mathrm{mg} \mathrm{L}^{-1}$, in the treatments with aquatic species, in six collection periods. DMS for collection periods $=81.62 ; \mathrm{CV}(\%)=30.33$ classification on lowercase letters. DMS for aquatic species $=91.04$; $\mathrm{CV}(\%)=31.25$ classification on capital letters. Tukey Test was applied at the level of $5 \%$ probability. 
the $\mathrm{NH}_{4}^{+}$concentrations in the effluent were lower and statistically differ from the others.

Zimmo et al. (2003) verified that the $\mathrm{NH}_{3}$ volatilization rates in ponds with algae were higher than in ponds with aquatic plants (Lemna gibba). According to the authors, it can be explained by the lower $\mathrm{NH}_{3}$ values in ponds with plants due to the shadowing and to the lower $\mathrm{pH}$ values. In this case, the volatilization rate correlated to the free $\mathrm{NH}_{3}$ concentration in the water of the pond.

When considering the percentages of reduction of the $\mathrm{NH}_{3}$ volatilization rates, it is possible to notice that the treatment systems with the species Eichhornia crassipes (Mart.) Solms and Salvinia auriculata Aubl. were more expressive, $77.8 \%$ and $76.2 \%$ in a 27 day retention time. This reduction in the $\mathrm{NH}_{3}$ volatilization shows the importance of the presence of aquatic plants in these treatment systems. Oron et al. (1988), when evaluating the treatment of domestic sewage under cultivation of floating aquatic plants of the family Lemnaceae, obtained $\mathrm{NH}_{3}$ removal efficiency of $90.0 \%$, with a 10 day retention time and initial concentration of $520 \mathrm{mg} \mathrm{L}^{-1}$ of COD. Researches carried out in wetlands that treated pig slurry waters mention that the $\mathrm{NH}_{3}$ volatilization represented less than $20.0 \%$ of the $\mathrm{N}$ removed by the wetlands (Poach et al., 2002).

\section{Conclusions}

The presence of aquatic macrophytes promoted the reduction of $\mathrm{NH}_{4}^{+}$concentration and of the $\mathrm{pH}$ values of swine fluids, and this resulted in the reduction of $\mathrm{NH}_{3}$ volatilization rates to the environment, with emphasis on the system with Eichhornia crassipes (Mart.) Solms, which presented the lowest rate of volatilization.

\section{References}

ANDRADE, J.C.M., TAVARES, S.R.L. and MAHLER, C.F., 2007. Fitorremediação: o uso de plantas na melhoria da qualidade ambiental. São Paulo: Oficina de Textos. 176 p.

ASSOCIAÇÃO BRASILEIRA DOS CRIADORES DE SUÍNOS - ABCS, 2014. Produção de suínos: teoria e prática. 1st ed. Brasília: ABCS. 905 p.

ASSUNÇÃO, F.A.L., 2009. Estudo da remoção de nitrogênio, com ênfase na volatilização de amônia, em lagoas de polimento de efluentes de reatores UASB tratando esgotos urbanos de Belo Horizonte/MG. Belo Horizonte: Universidade Federal de Minas Gerais, 89 p. Dissertação de Mestrado em Saneamento, Meio Ambiente e Recursos Hídricos.

BORTOLOTTO, I.M. and GUARIM NETO, G., 2005. O uso do camalote, Eichhornia crassipes (Mart.) Solms, Pontederiaceae, para confecção de artesanato no Distrito de Albuquerque, Corumbá, MS, Brasil. Acta Botanica Brasílica, vol. 19, no. 2, pp. 331-337. http://dx.doi.org/10.1590/S0102-33062005000200016.

BRIX, H., 1993. Wastewater treatment in constructed wetlands: system design, removal processes, and treatment performance. In: G.A. MOSHIRI, ed. Constructed wetlands for water quality improvement. Boca Raton: CRC Press, pp. 9-22.
CANTARELLA, H. and TRIVELIN, P.C.O., 2001. Determinação de nitrogênio total em solos. In: B. RAIJ, J.C. ANDRADE, H. CANTARELLA and J.A. QUAGGIO, eds. Análise química para avaliação da fertilidade de solos tropicais. Campinas: Instituto Agronômico de Campinas, pp. 262-269.

CARDOSO, L.R., MARTINS, D., MORI, E.S. and TERRA, M.A., 2005. Variabilidade genética entre populações de Pistia Stratiotes. Planta Daninha, vol. 23, no. 2, pp. 181-185. http:// dx.doi.org/10.1590/S0100-83582005000200003.

CENTRO DE PESQUISAS METEOROLÓGICAS E CLIMÁTICAS APLICADAS A AGRICULTURA - CEPAGRI, 2017 [viewed 24 April 2017]. Clima dos municípios paulistas [online]. Campinas: Unicamp. Available from: http://www.cpa.unicamp.br/outrasinformacoes/clima_muni_467.html

CONSELHO NACIONAL DO MEIO AMBIENTE - CONAMA, 2011. Resolução Conama $n^{\circ} 430$ de 13 de maio de 2011. Dispõe sobre as condições e padrões de lançamento de efluentes, complementa e altera a Resolução $n$. 357, de 17 de março de 2005, do Conselho Nacional do Meio Ambiente - CONAMA. Diário Oficial da República Federativa do Brasil, Brasília, DF, n. 92, 16 maio, p. 89.

ESTEVES, F.A., 1998. Fundamentos de limnologia. 2nd ed. Rio de Janeiro: Interciência. 602 p.

FELIX, E.P. and CARDOSO, A.A., 2004. Amônia $\left(\mathrm{NH}_{3}\right)$ atmosférica: fontes, transformação, sorvedouros e métodos de análise. Quimica Nova, vol. 27, no. 1, pp. 123-130. http://dx.doi. org/10.1590/S0100-40422004000100022.

GENTELINI, A.L., GOMES, S.D., FEIDEN, A., ZENATTI, D., SAMPAIO, S.C. and COLDEBELLA, A., 2008. Produção de biomassa das macrófitas aquáticas Eichhornia crassipes (aguapé) e Egeria densa (egeria) em sistema de tratamento de efluente de piscicultura orgânica. Ciências Agrárias, vol. 29, no. 2, pp. 441-448. http://dx.doi.org/10.5433/1679-0359.2008v29n2p441.

GOMES, M.A.C., 2011. Efeito da salinidade sobre a biomassa, morfologia e fisiologia de Salvinia auriculata Aubl. Campos dos Goytacazes: Universidade Estadual do Norte Fluminense Darcy Ribeiro, 90 p. Dissertação de Mestrado em Biociências e Biotecnologia.

GONZATTO, R., MIOLA, E.C.C., DONEDA, A., PUJOL, S.B., AITA, C. and GIACOMINI, S.J., 2013. Volatilização de amônia e emissão de óxido nitroso após aplicação de dejetos líquidos de suínos em solo cultivado com milho. Ciência Rural, vol. 43, no. 9, pp. 1590-1596. http://dx.doi.org/10.1590/S010384782013000900009 .

GRANATO, M., 1995. Utilização do aguapé no tratamento de efluentes com cianetos. Rio de Janeiro: CETEM/CNPq. 39 p. Série Tecnologia Ambiental, vol. 5.

HARPER, L.A., SHARPE, R.R., PARKIN, T.B., VISSCHER, A., VAN CLEEMPUT, O. and BYERS, F.M., 2004. Nitrogen cycling through swine production systems: Ammonia, dinitrogen, and nitrous oxide emissions. Journal of Environmental Quality, vol. 33, no. 4, pp. 1189-1201. http://dx.doi.org/10.2134/jeq2004.1189. PMid: 15254100

HENRY-SILVA, G.G. and CAMARGO, A.F.M., 2000a. Composição química de quatro espécies de macrófitas aquáticas e possibilidade de uso de suas biomassas. Naturalia, vol. 26, no. 8, pp. 111-125.

HENRY-SILVA, G.G. and CAMARGO, A.F.M., 2000b. Impacto do lançamento de efluentes urbanos sobre alguns ecossistemas 
aquáticos do município de Rio Claro (SP). Revista Ciências Biológicas e do Ambiente, vol. 2, pp. 317-330.

HENRY-SILVA, G.G. and CAMARGO, A.F.M., 2006. Efficiency of aquatic macrophytes to treat Nile tilapia pond effluents. Scientia Agrícola, vol. 63, no. 5, pp. 433-438. http://dx.doi.org/10.1590/ S0103-90162006000500003.

HENRY-SILVA, G.G. and CAMARGO, A.F.M., 2008. Tratamento de efluentes de carcinicultura por macrófitas aquáticas flutuantes. Revista Brasileira de Zootecnia, vol. 37, no. 2, pp. 181-188. http:// dx.doi.org/10.1590/S1516-35982008000200002.

HUNT, P.G. and POACH, M.E., 2001. State of the art for animal wastewater treatment in constructed wetlands. Water Science and Technology, vol. 44, no. 11-12, pp. 19-25. http://dx.doi. org/10.2166/wst.2001.0805. PMid:11804093.

JOHNSTON, C.A., 1991. Sediment and nutrient retention by freshwater wetlands: effects on surface water quality. Critical Reviews in Environmental Control, vol. 21, no. 5-6, pp. 491-565. http://dx.doi.org/10.1080/10643389109388425.

KADLEC, R.H. and KNIGHT, R.L., 1996. Treatment wetlands. Boca Raton: Lewis Publishers. 893 p.

KIEHL, E.J., 1985. Fertilizantes orgânicos. Piracicaba: Agronômica Ceres. 492 p.

KISSMANN, K.G. and GROTH, D., 1997. Plantas infestantes e nocivas. 2nd ed. São Paulo: BASF Brasileira.

KNIGHT, R.L., PAYNE-JÚNIOR, V.W.E., BORER, R.E., CLARKE-JÚNIOR, R.A. and PRIES, J.H., 2000. Constructed wetlands for livestock wastewater management. Ecological Engineering, vol. 15, no. 1-2, pp. 41-55. http://dx.doi.org/10.1016/ S0925-8574(99)00034-8.

KÖRNER, S. and VERMAAT, J.E., 1998. The relative importance of Lemna gibba, bacteria and algae for the nitrogen and phosphorus removal in duckweed - covered domestic wastewater. Water Research, vol. 32, no. 12, pp. 3651-366. http://dx.doi.org/10.1016/ S0043-1354(98)00166-3.

LIN, Y.F., JING, S.R., LEE, D.Y., CHANG, Y.F., CHEN, Y.M. and SHIH, K.C., 2005. Performance of a constructed wetland treating intensive shrimp aquaculture wastewater under high hydraulic loading rate. Environmental Pollution, vol. 134, no. 3, pp. 411-421. PMid:15620586.

LORENZI, H. 1982. Plantas daninhas do Brasil: terrestres, aquáticas, parasitas, tóxicas e medicinais. São Paulo: Nova Odessa. $425 \mathrm{p}$

LUTZENBERGER, J., 1985. Ecologia: do jardim do poder. Porto Alegre: L\&PM Editores, 102 p.

MALAVOLTA, E., VITTI, G.C. and OLIVEIRA, S.A., 1997. Avaliação do estado nutricional das plantas: princípios $e$ aplicações. 2nd ed. Piracicaba: Potafós. 319 p.

MEADE, G., PIERCE, J.V., O’DOHERTY, C., MUELLER, G., LANIGAN, G. and MC CABE, T., 2011. Ammonia and nitrous oxide emissions following land application of high and low nitrogen pig manures to winter wheat at three growth stages. Agriculture, Ecosystems \& Environment, vol. 140, no. 1-2, pp. 208-217. http://dx.doi.org/10.1016/j.agee.2010.12.007.

METCALF, E. and TCHOBANOGLOUS, G., 1991. Wastewater engineering: treatment, disposal and reuse. 3rd ed. New York: MacGraw Hill.
MKHABELA, M.S., GORDON, R., BURTON, D., SMITH, E. and MADANI, A., 2009. The impact of management practices and meteorological conditions on ammonia and nitrous oxide emissions following application of hog slurry to forage grass in Nova Scotia. Agriculture, Ecosystems \& Environment, vol. 130, no. 1-2, pp. 41-49. http://dx.doi.org/10.1016/j.agee.2008.11.012.

OLIVEIRA, P., 1981. Plantas de aquário. Lisboa: Editorial Presença. $238 \mathrm{p}$.

ORON, G., DE-VEGT, A. and PORATH, D., 1988. Nitrogen removal and conversion by duckweed grown on wastewater. Water Research, vol. 22, no. 2, pp. 179-184. http://dx.doi. org/10.1016/0043-1354(88)90076-0.

PENG, J.F., WANG, B.Z. and WANG, L., 2005. Mult- stage ponds-wetlands ecosystem for effective wastewater treatment. Journal of Zhejiang University. Science, vol. 6B, no. 5, pp. 346352. http://dx.doi.org/10.1631/jzus.2005.B0346.

POACH, M.E., HUNT, P.G., SADLER, E.J., MATHENY, T.A., JOHNSON, M.H., STONE, K.C., HUMINEK, F.J. and RICE, J.M., 2002. Ammonia volatilization from constructed wetlands that treat swine wastewater. Transactions of the ASAE. American Society of Agricultural Engineers, vol. 45, no. 3, pp. 619-627. http://dx.doi.org/10.13031/2013.8825.

POACH, M.E., HUNT, P.G., VANOTTI, M.B., STONE, K.C., MATHENY, T.A., JOHNSON, M.H. and SADLER, E.J., 2003. Improved nitrogen by constructed wetlands receiving partially nitrified swine manure. Ecological Engineering, vol. 20, no. 2, pp. 183-197. http://dx.doi.org/10.1016/S0925-8574(03)00024-7.

POTT, V.J. and POTT, A., 2000. Plantas aquáticas do Pantanal. Brasília: Embrapa; Corumbá: Centro de Pesquisa Agropecuária do Pantanal. 404 p.

REIDEL, A., DAMASCENO, S., ZENATTI, D.C., SAMPAIO, S.C., FEIDEN, A. and QUEIROZ, M.M.F., 2005. Utilização de efluente de frigorífico, tratado com macrófita aquática, no cultivo de tilápia do Nilo. Revista Brasileira de Engenharia Agrícola e Ambiental, vol. 9, suppl, pp. 181-185.

ROS, C.O., AITA, C. and GIACOMINI, S.J., 2005. Volatilização de amônia com aplicação de uréia na superfície do solo, no sistema plantio direto. Ciência Rural, vol. 35, no. 4, pp. 799-805. http:// dx.doi.org/10.1590/S0103-84782005000400008.

SCHMIDELL, W., SOARES, H.M., ETCHEBEHERE, C., MENES, R.J., BERTOLA, N.C. and CONTRERAS, E.M., 2007. Tratamento biológico de águas residuárias. Florianópolis: Tribo da Ilha.

SCULTHORPE, C.D., 1967. The biology of aquatic vascular plants. London: Edward Arnold Ltd. 610 p.

SEZERINO, P.H. and PHILIPPI, L.S., 2000. Utilização de um sistema experimental por meio de "wetland" construído no tratamento de esgotos domésticos pós tanque séptico. In: Anais do Simpósio Luso-Brasileiro de Engenharia Sanitária e Ambiental; 2000; Porto Seguro. Rio de Janeiro: ABES, pp. 688-697.

SHAH, M., HASHMI, H.N., GHUMMAN, A.R. and ZEESHAN, M., 2015. Performance assessment of aquatic macrophytes for treatment of municipal wastewater. Journal of the South African Institution of Civil Engineering, vol. 57, no. 3, pp. 18-25. http:// dx.doi.org/10.17159/2309-8775/2015/V57N3A3.

SILVA, A.D.R., SANTOS, R.B., BRUNO, A.M.S.S., GENTELINI, A.L., SILVA, A.H.G. and SOARES, E.C., 2014. Eficiência do aguapé sobre variáveis limnológicas em canais de abastecimento 
utilizados no cultivo de tambaqui. Acta Amazonica, vol. 44, no. 2 , pp. 255-262. http://dx.doi.org/10.1590/S0044-59672014000200011.

SOMMER, S.G. and HUTCHINGS, N.J., 2001. Ammonia emission from field applied manure and its reduction: invited paper. European Journal of Agronomy, vol. 15, no. 1, pp. 1-15. http://dx.doi.org/10.1016/S1161-0301(01)00112-5.

SOOKNAH, R.D. and WILKIE, A.C., 2004. Nutrient removal by floating aquatic macrophytes cultured in anaerobically disgested flushed dairy manure wastewater. Ecological Engineering, vol. 22, no. 1, pp. 27-42. http://dx.doi.org/10.1016/j.ecoleng.2004.01.004.

STEINMETZ, R.L.R., KUNZ, A., DRESSLER, V.L., FLORES, É.M.M. and MARTINS, A.F., 2009. Study of metal distribution in raw end screened swine manure. Clean Soil Air Water, vol. 37, no. 3, pp. 239-244. http://dx.doi.org/10.1002/clen.200800156.
STONE, K.C., HUNT, P.G., HUMENIK, F.J. and JOHNSON, M.H., 1998. Impact of swine waste application on ground and stream water quality in an Eastern Coastal Plain watershed. American Society of Agricultural and Biological Engineer, vol. 41, no. 6, pp. 1665-1670. http://dx.doi.org/10.13031/2013.17342.

UNITED STATES ENVIRONMENTAL PROTECTION AGENCY - EPA, 2000 [viewed 03 November 2017]. Introduction to phytoremediation. Cincinnati, Ohio: EPA. EPA/600/R-99/107. Available from: http://nepis.epa.gov

VESILIND, P.A. and MORGAN, S.M., 2011. Introdução à engenharia ambiental. 2nd ed. São Paulo: Cengage Learning. 438 p.

ZIMMO, O., VAN DER STEEN, N. and GIJZEN, H., 2003. Comparison of ammonia volatilization rates in algae and duckweedbased waste stabilization ponds treating domestic wastewater. Water Research, vol. 37, no. 19, pp. 4587-4594. http://dx.doi. org/10.1016/j.watres.2003.08.013. PMid:14568043. 